\title{
The relationship between psychological capital and academic performance of social work students
}

\author{
Adams Ogirima \\ Onivehu
}

\section{Contact \\ University of Ilorin Faculty of Education P.M.B. 1515, llorin Kwara State, Nigeria}

Correspondence: adamsonivehu@gmail.com

Copyright (C) 2020 by the author and publisher, TBU in Zlín.

This work is licensed under the Creative Commons Attribution International License (CC BY).

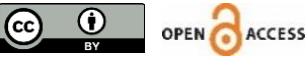

\begin{abstract}
The Nigerian society emphasizes the importance of academic achievement as a major yardstick for measuring students' ability and the effectiveness of the educational system. Thus, the academic performance of social work students has been the prime tool for admission into higher schools, employment and even the choice of future career. The present study investigated the relationship between psychological capital and academic performance of social work students in University of Ilorin, Ilorin, Nigeria. The descriptive survey research method of correlational type was adopted for the study. The study population consisted of all students in the Department of Social Work who were enrolled in the 2018-2019 academic year. The sample included 180 third and fourth year students, selected by simple random sampling. The research instrument for the collection of data was the Luthans's Psychological Capital Questionnaire (PCQ) and a pro forma. Three research questions were raised and one null hypothesis was formulated and tested. Data were subjected to frequency counts, percentage, correlation analysis and multiple regression. The results of this study showed that there is a significant positive relationship between the four factors of psychological capital (resilience, hope, optimism and self-efficacy) with academic performance. It was recommended that psychological capital should be incorporated into the social work curriculum in Nigerian universities so as to boost the level of students' performance in the social work programme.
\end{abstract}

Keywords: psychological capital, academic performance, social work students

\section{Vztah mezi psychologickým kapitálem a akademickými výsledky u studentů sociální práce}
Abstrakt: Nigerijská společnost klade důraz na akademické výsledky jako na měŕitko schopností studentů a efektivitu vzdělávacího systému. Proto jsou akademické výsledky studentů sociální práce primárním nástrojem pro přijetí na vyšší stupně škol, do zaměstnání i pro výběr budoucího povolání. Předkládaná studie zkoumala vztah mezi psychologickým kapitálem a akademickými výsledky u studentů sociální práce na nigerijské University of Ilorin. Byla zde použita výzkumná metoda deskriptivního průzkumu korelačního typu. Průzkumným 
vzorkem byli všichni studenti katedry sociální práce, kteří se zapsali pro školní rok 2018-2019. Vzorek obsahoval 180 studentů třetího a čtvrtého ročníků vybraných jednoduchým náhodným vzorkováním. Výzkumným nástrojem pro sběr dat byl Luthanův dotazník psychologického kapitálu (PCQ) a pro forma. Položeny byly tři výzkumné otázky a byla formulována a testována jedna nulová hypotéza. Data byla podrobena frekvenčním výpočtům, stanovení procenta, korelační analýze a mnohonásobné regresi. Výsledky této studie ukázaly, že existuje významný pozitivní vztah mezi čtyřmi faktory psychologického kapitálu (odolnost, naděje, optimismus a osobní výkonnost) a akademickými výsledky. Bylo doporučeno, aby byl psychologický kapitál začleněn do osnov oboru sociálních prací na nigerijských univerzitách za účelem zvýšení úrovně výkonu studentů v programu sociálních prací.

Klíčová slova: psychologický kapitál, akademické výsledky, studenti sociální práce

\section{Introduction}

The advent of 21 century has significantly changed the level of human development in Nigeria. Resultantly, Nigeria, which is undoubtedly the most populous black nation in the world has recorded significant improvements in various spheres, such as science and technology, medicine, literature, peace, human resource development, international co-operation and socio-economic development. Nonetheless, the spate of development in Nigeria is worrisomely below expectation due to a myriad of contemporary social problems such as terrorism, ethno-religious conflicts wars, internal displacement, massive corruption, human trafficking, electoral violence, kidnapping, child abuse, poverty, inequality, unemployment, drug abuse, cybercrime among others (Omilusi, 2016; Osemeke, 2011; Shuaibu, Salleh, \& Shehu, 2015; Uzorma \& Nwanegbo-Ben, 2014). In order to effectively address these social problems in Nigeria, there is no doubt that education has a great role to play. To this end, university education, which is a germane component of the Nigerian tertiary education system is key and as such, a plethora of academic programmes have been approved by the Nigerian Universities Commission (NUC) for various public and private universities that are spread across the length and breadth of Nigeria. This is in view of the fact that the theory and practice of most academic programmes which includes social work is tailored towards dealing with pressing societal issues (Kraimer \& Altmeye, 2018).

Hence, social work students in Nigerian universities are exposed to various learning experiences that are designed to enable students acquire the requisite skills, knowledge and competence for the effective practice of social work in various areas such as personal and family development, community development, policy formulation and development, health promotion, law and social service and a host of others in the future (Uche, Uche, Eme, \& Ebue, 2014). To this end, it goes without saying that the extent to which the diverse objectives of social work education are being achieved in Nigeria is primarily a function of the level of students' academic performance. However, the academic performance of social work students could be attributed to a complex interplay of some variables that might be personal, social, academic and institutional in nature (Adegunju, Onivehu, Odetunde, \& Oyeniran, 2017; Bamidele \& Bamidele, 2013; Onivehu, Adegunju, Ohawuiro. \& Oyeniran, 2018; Onivehu \& Ohawuiro, 2018).

Therefore, it is integral to understand the relationship between psychological factors or resources and the academic performance of social work students. In this sense, psychological capital is increasingly 
being investigated as a prime determinant of students' academic performance. Thus, studies have revealed that the psychological capital components of hope, self-efficacy, optimism and resilience had a positive influence on the students' academic performance (Luthans, Luthans, \& Jensen, 2012; Mwangi, Okatcha, Kinai, \& Ireri, 2015; Vanno, Kaemkate, \& Wongwanich, 2014). Therefore, this study focused on the relationship between psychological capital (self-efficacy, hope, optimism and resilience) and academic performance of social work students in University of Ilorin, llorin, Nigeria with a view to foster the success of the social work education programme in Nigerian universities.

\section{The theoretical framework}

The main focus of this section to explain some relevant concepts and theoretical underpinnings that are related to the focus of the study.

\subsection{Concept of psychological capital}

Psychological capital is a positive organizational behaviour construct that emanated from the field of positive psychology. Essentially, positive psychology stresses that the quality of our lives depends both on what we do and how we experience what we do. According to Carr (2004), it encompasses the psychological or mental state of an individual. Psychological capital is a broad term which defies a singular definition. Luthans, Youssef and Avolio (2007) defined psychological capital as an individual's positive state of development. Psychological capital entails having confidence (self-efficacy) to take on and put in the necessary effort to succeed at challenging tasks; making positive attributions (optimism) about succeeding now and in the future; persevering toward goals and, when necessary, redirecting paths to goals in order to succeed when beset by problems and adversity (hope) and sustaining and bouncing back and even beyond (resilience) to attain success (Lunnbrg, 2010; Luthans et al., 2007). Furthermore, Luthans and Youssef-Morgan (2017) posited that PsyCap comprises of four psychological resources (hope, optimism, self-efficacy and resilience) which interacts in a systematic and synergetic manner. Similarly, Kutanis and Oruc (2014) opined that psychological capital refers to the external resources (optimism and resilience) and internal resources (self-efficacy and hope) required by a person to live a fulfilled and happy life.

\subsection{Concept of hope}

Hope is one component of PsyCap that is future oriented and considered to be multidimensional by most researchers. It is an affective variable that motivates action and affects the thoughts and behaviours of people. The conceptualization of hope construct is closely linked with Snyder, a clinical psychologist. Snyder et al. (1991) based their theory of hope on three key mental components, namely goals, willpower (agencies), and way power (pathways). Hope according to Snyder, Rand and Sigmon (2002) is described as a cognitive construct that is based on a reciprocally derived sense of successful goal-directed determination (agency) and planning (pathways) to meet the envisaged goals. Thus, hope theory begins with envisioning goals as a major component that influences human behavior (Snyder et al., 2002). It suggests that goals on their own do not produce behavior but people's outlook of themselves. Goals are understood as something that individuals want to obtain (such as an object) or attain (such as an accomplishment) (Badran \& Youssef-Morgan, 2015).

Applying the concept of hope to the academic environment, the willpower (agency) enables learners to recognize and set goals that lead them to achieve intended performance outcomes (Luthans, Avey, \& Patera, 2008). Likewise, when learners possess the ability to generate multiple pathways to attain goals and solve problems relating to academic performance, they become more aware of their environments (Snyder et al., 2002). Students with high hope benefit immensely academically. When such students are faced with challenging situations, they do not give up but rather maintain a positive outlook and expect a positive outcome. As a result of the positive outcome expected, the individual is motivated to forge ahead despite the setbacks (Santilli, Nota, Ginevra, \& Soresi, 2014; Sharabi, Sade, 
\& Margalit, 2016). Also, as observed by Froman (2010) hopeful people persistently try to attain what they set out to accomplish even in difficult times and consequently find satisfaction when they eventually achieve their goals.

\subsection{Concept of optimism}

An optimist is generally viewed as a person who sees every cloud as possessing a silver lining and affirms that good will always come by him no matter the difficulties. Hayes and Weathington (2007) posited that optimism is a general expectation that the future will be good, as against pessimism which is the generalized expectancy that the future will be bad. In other words, an optimist generally wields a positive disposition when faced with challenges and expects events to turn out well at the tail end. Likewise, optimistic thinking motivates individuals to continually persist and work hard to find solutions irrespective of the odds. Optimism can be temperamental, that is, some people by nature are more positive about life, but at the same time it can also be learned with the right type of experiences. According to the concept of learned optimism, proposed by Seligman (1991), optimism can be enhanced in an individual by the selection of achievable goals.

Optimism has numerous benefits. Firstly, optimism has the natural tendency of promoting positive mood, and this in turn helps to ward off depression and anxiety in people. Secondly, optimism also encourages greater persistence in the face of obstacles, which consequently result in greater success. Moreover, Kleumper, Little and DeGroot (2009) from their investigation on the effects of optimism realized that it predicted to a large extent how students perform in a given task and their committal level in seeing that the task is well performed. Also, there is evidence that optimistic people actually look healthier than pessimistic people (Thomson, Schonert-Reichl, \& Oberle, 2015).Extant literature indicates that higher levels of optimism facilitated the way students in having more positive expectations of outcomes in the academic environment (Kapikiran, 2012; Mclntosh, Stern, \& Ferguson, 2004). Hence, students who take an optimistic approach to difficult situations will be better able to adjust and overcome challenges that accompany distant education, because their positive expectations will help them react better and give in their optimum best to realize academic gain despite the setbacks.

\subsection{Concept of self-efficacy}

The etiology of the concept of self-efficacy could be traced to the pionerring work carried out by Albert Bandura, which resulted in the formation of the socio-cognitive theory of human behavior. As a highorder construct of PsyCap (Luthans, Avolio, Avey, \& Norman, 2007) with a state-like structure, this PsyCap asset can be developed in learners. Self-efficacy can be defined according to Bandura's social cognitive theory as self confidence in being able to perform specific tasks successfully or meet the challenges that may arise. It is seen as an enthusiastic and independent concept closely linked with work-related performance (Luthans, Luthans, \& Luthans, 2004). Stajkovic and Luthans (1998) defined self-efficacy as the personal confidence an individual has on his or her ability to maximally mobilize motivation, cognitive resources or courses of action in order to successfully complete a specific task. Adeyemo and Agokei (2010) described the self efficacy as an individual's belief in his/ her ability to perform successfully in a given course. It therefore follows that academic self-efficacy refers to a learner's effort and persistence that brings about achievement. In lieu of this, cognitive sources, motivation and the form of behaviour necessary to succeed in the given task must be mobilized and harnessed accordingly by learners (Luthans et al., 2007). This is pertinent because a learner's level of self-efficacy governs the amount of effort he/she will put in to complete a task even when faced with unexpected impediments (Ogunmakin \& Akomolafe, 2013; Ouweneel, Le Blanc, \& Schaufeli, 2012). Bandura (1997) classified self-efficacy ashigh and low. Thus, students with low self-efficacy are generally considered to be academically at risk (Ofole \& Okopi, 2012). 


\subsection{Concept of resilience}

Most researchers view resilience as a multifaceted and strength-based construct that focuses on providing protective factors that enhance success in individuals (Schunk \& Zimmerman, 2008; Luthar, Lyman, \& Crossman, 2014). The American Psychological Association (2017) defined resilience as the process of adapting well in the face of adversity, trauma, tragedy, threats, or even significant sources of stress such as family and relationship problems, serious health problems, or workplace and financial stressors. Likewise, resilience is a broad set of cognitive, behavioural and emotional responses to acute or severe adversities which might be usual or unusual in nature. Luthans (2002) also opined that resilience is a positive psychological capacity that enables a person to rebound or bounce back from adversity, uncertainty, conflict, failure, or even positive change, progress and increased responsibility. In other words, resilient individuals forge ahead even after encountering strong oppositions or events such as personal adversity, conflict and/ or set backs. Consequently, resilience is essentially based on the strength of the individual and his or her coping resources to successfully resolve and/or manage challenging situations (Baumgardner \& Crothers, 2010).

Martin and Marsh (2009) also pointed out that resilience could also be viewed as a student's capacity to overcome acute or chronic adversities that are seen as major setbacks in the pursuit of academic goals. For instance, social work students might be faced with work pressures, time constraints, stressful and other negative factors. These setbacks might negatively affect the academic performance of social work students. Thus, the students' capability to overcome these academic setbacks, stress and other forms of challenges associated with university life by implementing internal and external protective factors is a function of resilience (Mwangi et al., 2015). Examples of such protective factors include cognitive abilities, temperament, positive self-image, emotional stability and sense of humour (Karmalkar \& Vaidya, 2018; Peterson, Luthans, Avolio, Walumbwa, \& Zhang, 2011). Specifically, internal protective factors mostly encompass the personality or dispositional attributes of the individual while external protective factors are majorly attributes that are subsequently developed by individuals and supports from people around them (Rahat \& Ihan, 2016).

Youssef and Luthans (2007) also differentiated resilience from other psychological capital components by arguing that resilience is both reactive and proactive in nature. By reactivity, it means the potential destructive impact that setbacks, traumas, and even positive but overwhelming events have on even the most hopeful and optimistic individuals cannot be whisked away. Rather resilience encourages individuals to recognize and acknowledge such impact and provides time, energy and resource investment for the individual to recuperate, rebound and return to a balanced point. Proactively, resilience also allows individuals to use setbacks as 'springboards' or opportunities to foster growth beyond that balance point.

\subsection{Psychological capital and students' academic performance}

Extant literature is replete with a plethora of studies on the relationship between psychological capital and students' academic performance. For instance, Luthans et al. (2012) found a significant and predictive relationship between the PsyCap of undergraduate business students and GPA results explaining 7\% of the variance. Vitanya, Wannee and Suwimon (2014) investigated the relationship between academic performance, perceived group PsyCap, and individual PsyCap of Thai undergraduate students and found that academic performance has positive direct effect on students' PsyCap. Feldman and Kubota (2015) investigated the relationship among hope, self-efficacy, optimism and academic achievement and found that hope predicted academic-specific hope and academic selfefficacy, both of which then predicted GPA. Likewise, Saeed and Murad (2015) examined the relationship between psychological capital, educational self-regulatory and intelligence beliefs with students' academic performance in the University of Applied Sciences in Abdanan County, Iran and found that between psychological capital, educational self-regulatory and intelligence beliefs with students' academic performance in University of Applied Sciences of Abdanan County and found that 
there is a significant positive relationship between the four subscales of psychological capital (hope, resilience, optimism and self-efficacy) with academic performance.

\section{Methodology}

The research design employed in this study was a correlation study. The study population for the study comprised all social work students in University of Ilorin, llorin, Nigeria while the target population was all 215 third and fourth year students. The sample included 180 third and fourth year students, selected by simple random sampling. The decision to choose third and fourth year students was due to the fact that they are nearing the point of graduation. The respondents were randomly selected across the academic levels totaling 180 students for this study. The instrument used in this study was a self-developed questionnaire which consisted of three sections (A, B and C). Section A elicited students biographic information. Section B contained a pro forma that was used to collect students' Grade Point Average (GPA). Section C elicited information on the psychological capital of the respondents. The items in the section were 24 which were adapted from Luthans et al. (2012) Academic Psychological Capital Scale. Specifically, the scale consists of Hope: items 7, 8, 9, 10, 11, 12; Efficacy: items 1, 2, 3, 4, 5, 6; Resilience: items 13R, 14, 15, 16, 17, 18; and Optimism: items 19, 20R, $21,22,23 R, 24$. Sample items on the A-PCS include: 1. "I feel confident analyzing a long-term problem to find a solution concerning my studies"; 2 ." I feel confident in representing my ideas concerning my group work in the classroom". Section C was patterned in Likert scale format of Strongly Agree (SA) = 6 points, Agree $(A)=5$ points, Somewhat Agree $(S W A)=4$ points, Somewhat Disagree $(S W D)=3$ point, Disagree $(D)=2$ points and Strongly Disagree $(S D)=1$ point. Thus, respondents who scored 24-71 points were considered as having a low level of psychological capital, the respondents who scored 72 96 points were adjudged to have an average level of psychological capital while respondents who scored 97-144 were taken as social work students with a high level of psychological capital.

The current CGPA of respondents were collected and scored as follows; high academic performance = $3.5-5.0$ average academic performance $=2.5-3.49$ and low academic performance $=1.5-2.49$. The validity of the scale was determined by using face and content validity where five experts in the Faculty of Education were required to assess the items on the scale before their application to this study. To ascertain the reliability of the scale, a pilot study was carried out on a random sample of 20 undergrduates (10 males and 10 females) from the Faculty of Education, University of Ilorin. This sample was not included in the main study. Thus, the reliability of the instrument was ascertained using test re-test method. Specifically, the internal consistency of the for each of the dimensions was: hope (.62); self-efficacy (.65); resilience (.60); and optimism (.61). Finally, the Cronbach's Alpha reliability coefficient of .67 was obtained for all dimensions, which is slightly above the thereshold of .60 , which is considered as a limit of acceptable reliability. Thus, the scale was found to be moderately reliable to be used for the present study. Data were subjected to frequency counts, percentage, correlation analysis and multiple regression.

\subsection{Research questions and hypothese}

The main aim of this study is to investigate the relationship between psychological capital and academic performance of social work students in University of Ilorin, Nigeria. Specifically, the study was guided by the following research questions:

RQ1: What is the level of psychological capital of social work students in University of Ilorin, Ilorin, Nigeria?

RQ2: What is the level of academic performance of social work students in University of Ilorin, Ilorin, Nigeria?

RQ3: What is the relationship among hope, optimism, self-efficacy, resilience and academic performance among social work students in University of Ilorin, Nigeria? 
The hypothesis tested withinn this study is as follows:

H1: Hope, optimism, self-efficacy and resilience influence academic performance of social work students in University of Ilorin, Ilorin, Nigeria.

\section{Results}

Table 1 shows respondents' gender, out of 180 respondents that were sampled, 85 (47.22\%) of the respondents were males while 95 (52.78\%) were females. Table 1 also indicates that $100(55.56 \%)$ of the respondents are third year students while $80(44.44 \%)$ of the respondents are fourth year students. From Table 1, it could be deduced that male social work students and their female counterparts in University of llorin, llorin, Nigeria participated in the study. Similarly, Table 1 indicates that third year students and their counterparts in the fourth year participated in the study. On the whole, it could be concluded that this sample fairly represents a cross-section of social work students in the University of Ilorin, llorin, Nigeria.

Table 1

Demographic distribution of respondents by gender and academic level

\begin{tabular}{llll}
\hline Variable & & Frequency & Percentage (\%) \\
\hline Gender & Male & 85 & 47.22 \\
& Female & 95 & 52.78 \\
Academic Level & Third year of study & 100 & 55.56 \\
& Fourth year of study & 80 & 44.44 \\
\hline
\end{tabular}

RQ1: What is the level of psychological capital of social work students in University of Ilorin, Ilorin, Nigeria?

Table 2 shows that $108(60.00 \%)$ of the respondents rated themselves within the high level of psychological capital, 47 (26.11\%) of the respondents had average levels of psychological capital while $25(13.39 \%)$ of the respondents had low levels of psychological capital. Thus, it could be inferred from Table 2, that about $86.11 \%$ of the respodents had a moderate level of psychological capital. This finding might be attributed to the importance of a moderate level of hope, optimism, self-efficacy and resilience in an academic environment that is characterised by several academic stressors and challenges. For instance, social work students in the University of llorin require a moderate level of hope, optimism, self-efficacy and resilence to stay motivated and focused in their academic pursuit for four years. Furthermore, the level of psychological capital among social work students in the University of llorin could be as a result of the supportive roles of lecturers, staff advisers, level advisers, Student Union executives, religious organizations, the Students Affairs Unit and the University's Counselling and Human Development Centre, as well as the social support of family members, intimate partners, classmates, hostel mates and significant others in the university community.

Table 2

Distribution of respondents by levels of psychological capital

\begin{tabular}{llll}
\hline Variable & & Frequency & Percentage (\%) \\
\hline Levels of psychological capital & High & 108 & 60.00 \\
& Average & 47 & 26.11 \\
& Low & 25 & 13.89 \\
\hline
\end{tabular}


RQ2: What is the level of academic performance of social work students in University of Ilorin, Ilorin, Nigeria?

Table 3 presents the level of academic performance of social work students in University of Ilorin, Nigeria. Hence, 94 (52.22\%) of the respondents were categorized as being high in academic performance, $56(31.11 \%)$ of the respondents were categorized as being average in academic performance while $30(16.67 \%)$ of the respondents were categorized as being low in academic performance. The results presented in Table 3 could be attributed to the importance attached to a high level of academic performance in the Nigerian university system. Given that this set of respodents are third and fourth year students nearing the point of graduation, it would be expected that all efforts would be put in place by such students in order to graduate with a good CGPA or a high class of degree that would be appreciated by the employers of labour in a highly competitive labour market. Nonethless, it should noted that the level of academic performnance of the respodents was collected through a self-report, and as such it might be possible that some of the respondents were biased in their responses with regards to the level of academic performnance.

Table 3

Distribution of respondents by levels of academic performance

\begin{tabular}{llll}
\hline Variable & & Frequency & Percentage (\%) \\
\hline Levels of academic performance & High & 94 & 52.22 \\
& Average & 56 & 31.11 \\
& Low & 30 & 16.67 \\
\hline
\end{tabular}

RQ3: What is the relationship among hope, optimism, self-efficacy, resilience and academic performance among social work students in University of Ilorin Ilorin, Nigeria?

Table 4 indicates the relationship among hope, optimism, self-efficacy and academic performance of social work students in University of Ilorin. There was a significant positive correlation between academic performance and all of the predictor variables (hope, optimism, self-efficacy and resilience) with the exception of self-efficacy which was negatively correlated with academic performance. Likewise, self-efficacy had a negative correlation with all of the other predictor variables, which in turn had a positive correlation with each other. Table 4 also indicates the descriptive statistics for the relationship among the variables in the present study. Thus, the highest mean was observed in the self-efficacy scores $(M=16.73)$, whereas the lowest mean was found in the optimism scores $(M=9.53)$. In a like manner, the standard deviation score of 3.01 of self-efficacy scores was the highest while optimism scores had the least standard deviation of 2.02 .

This finding implies that the mean difference was in favour of the social work students with a high level of self efficacy, with higher scores indicating that social work students in the University of Ilorin are confident and motivated enough to harness cognitive resources in order to successfully carry out several academic-related tasks such assignments, field works, personal study, tests and examinations. Thus, the general and academic self-efficacy of social work students in University of Ilorin should be enhanced through effective psychosocial interventions and programmes. 
Table 4

Correlation matrix for the relationship among hope, optimism, self-efficacy, resilience and academic performance among social work students in University of llorin

\begin{tabular}{llllll}
\hline Variable & 1 & 1 & 3 & 4 & 5 \\
\hline 1. Academic Performance & 1 & & & & \\
2. Hope & $.74^{* *}$ & 1 & & & \\
3. Optimism & $.42^{* *}$ & $.48^{* *}$ & 1 & & \\
4. Self-efficacy & $-.57^{* *}$ & $-.75^{* *}$ & $-.43^{* *}$ & 1 & \\
5. Resilience & $.28^{* *}$ & $.23^{* *}$ & $-.26^{* *}$ & $-.33^{* *}$ & 1 \\
\hline Mean & 17.22 & 10.34 & 9.53 & 16.73 & 10.57 \\
SD & 3.23 & 2.05 & 2.02 & 3.01 & 2.08 \\
\hline
\end{tabular}

Note: ${ }^{* *}=$ Significance at $\mathrm{p}<.01$

H1: Hope, optimism, self-efficacy and resilience influence academic performance of social work students in University of Ilorin, Ilorin, Nigeria.

Table 5 indicates that the calculated F-value is 68.35 with significant probability value of .000 which is less than alpha value of .05 . Since the probability value is lesser than the alpha value, the null hypothesis was rejected. By implication, hope, optimism, self-efficacy and resilience can predict academic performance of social work students in University of llorin. To examine the contributions of the independent variables (hope, optimism, self-efficacy and resilience) to the model (academic performance), R-square was computed and the output reveals thus:

Table 5

Regression analysis of tested hypothesis

\begin{tabular}{|c|c|c|c|c|c|c|}
\hline Model & $\begin{array}{l}\text { Sum of } \\
\text { squares }\end{array}$ & Df & $\begin{array}{l}\text { Mean } \\
\text { squares }\end{array}$ & $\begin{array}{l}\text { Calculated } \\
\text { F-value }\end{array}$ & Sig. & Decision \\
\hline Regression & 3736.021 & 4 & 3427.015 & & & \\
\hline Residual & 1556.623 & 175 & 43.140 & & & Rejected \\
\hline Total & 5292.644 & 179 & & $68.35^{*}$ & .000 & \\
\hline
\end{tabular}

Notes: Critical level of sig. $=.05$; Independent variables: Hope, optimism, self-efficacy and resilience; Dependent variable: Academic performance

Table 6 revealed that the independent variables (hope, optimism, self-efficacy and resilience) together explain R-square .360 representing $36.0 \%$ of the variance in the academic performance of social work students, which is highly significant as also indicated by the F-value (68.35). By implication, $64.0 \%$ of the total variance of the dependent variable (academic performance) was not accounted for by the combination of the four independent variables (hope, optimism, self-efficay and resilience). In other words, it is possible that there are some other salient factors apart from psychological capital that could influence the academic performnance of social work studnets in the University of llorin. For instance, llorin is the capital city of Kwara State, Nigeria. Hence, social work students in the University of llorin have access to various social activities in a broad spectrum of entertainment spots, night clubs, sports betting centres and football viewing centres that are located within and outside the school environment. More so, it is possible that the phenomenon of multitasking with various mobile devices such as Smartphones, Tablet Pcs and Laptops for non-academic purposes during study or lecture periods could be responsible for the reported level of academic performance among social work students. Thus, some of these offline and online social activies might distract some students from focusing on their studies, thereby influencing the level of students' academic performance. Furthermore, other factors that might influence the academic performnance of social work students might include psychosocial variables such as achievement motivation, emotional intelliegence, selfesteem, locus of control, subjective wellbeing as well as home-related factors such socio-economc status and family type. 
Table 6

Contributions of the independent variables on the dependent variable

\begin{tabular}{llllll}
\hline Model summary* & $\begin{array}{l}\text { Unstandardized } \\
\text { Coefficients }\end{array}$ & & $\begin{array}{l}\text { Standardized } \\
\text { Coefficients }\end{array}$ & t-value & Sig. \\
\hline (Constant) & B & Std. Error & Beta & & \\
Hope & 45.372 & .444 & & 73.128 & .000 \\
Optimism & 5.350 & .736 & .721 & 8.420 & .000 \\
Self-Efficacy & .0624 & .672 & .591 & 7.371 & .000 \\
Resilience & .115 & .050 & .312 & 3.285 & .004 \\
\hline
\end{tabular}

Note: ${ }^{*}$ Multiple $\mathrm{R}=.549 ;$ Multiple $\mathrm{R}^{2}=.360$; Multiple $\mathrm{R}^{2}$ (adjusted) $=.216$; Standard error estimate $=$ .621.

In order to examine the contributions of each of the independent variables, Beta weight were computed and output revealed that hope contributed beta weight of 5.350 and .721 . It is followed by optimism which contributed Beta weight of .624 and .591. Likewise, the Beta weight of self-efficacy was .115 and .312 while the Beta weight of reslinece was .051 and .530 respectively. This implies that hope is the most significant of all the independent variables that contributed more to dependent variable (academic performance). In a like manner, optimism, resilience and self-efficacy contributed in various dimensions to the academic performance of social work students in University of Ilorin. Nonetheless, self-efficacy contributed less to the dependent variable (academic performance).

\section{Discussion}

Extant literature has focused on the relationship between psychological capital and academic performance in other countries as well in other academic disciplines, however, little is known about the relationship between psychological capital and academic performance of social work students in the University of Ilorin, llorin, Nigeria. Hence, the research aimed to determine the relationship between psychological capital and academic performance of social work students in the University of Ilorin, Ilorin, Nigeria. Based on the research questions answered and hypothesis tested, it was revealed that the psychological capital of social work students in the University of Ilorin was moderate. This could be attributed to the data obtained from the field that the students sampled had $60 \%$ high psychological capital. In the same vein, they had $52.22 \%$ high level of academic performance. This finding is in agreement with Saeed and Murad (2015) who observed that relationship there is a

The results indicated that there is a significant positive relationship between psychological capital (resilience, hope, optimism and self-efficacy) and academic performance of social work students. significant positive relationship between psychological capital (hope, resilience, optimism and self-efficacy) and academic performance of students in the University of Applied Sciences in Abdanan County, Iran. Similarly, this finding is in support of Feldman and Kubota (2015) who found that hope and academic self-efficacy significantly predicted students' GPA. Supporting this finding, Luthans, Luthans and Jensen (2012) found a significant and predictive relationship between the psychological capital and the Grade Point Average (GPA) of undergraduate business students. Furthermore, the findings indicated that hope is the most significant predictor of academic performance among social work students in the University of Ilorin. This finding could be attributed to the findings of some studies which indicates that students with a high level of hope tend to expect positive outcomes from challenging situations in the academic environment (Santilli et al., 2014; Sharabi et al., 2016). 


\section{Conclusion}

Based on the data collected, analyzed and interpreted, it could be concluded that social work students in the University of Ilorin had 108 (60\%) of the social work students in University of Ilorin had a high level of psychological capital while 94 (52.22\%) of the respodents had above average level of academic performance. It is the submission of the researcher based on the data collected, analyzed and interpreted that psychological capital is a good determinant of academic performance among social work students in the University of llorin. In the course of this study, it is also ascribed that hope as a sub-component of psychological capital influenced students' academic performance by contributing significantly to the academic performance of social work students in the University of Ilorin.

\subsection{Recommendations}

Since psychological capital had a positive significant relationship with the academic performance of social work students in the University of Ilorin, the following recommendations are proffered:

1. Curriculum experts could develop and integrate psychological capital in university education curriculum especially social work education.

2. Newly admitted social work students should be give orientation on how to integrate the concept of psychological capital into their day to day activities so as to enhance high level of academic performance among social work students.

3. There should be periodical sensitization workshops/seminars for university administrators, lecturers and social work students in an attempt to manage and improve psychological capital of social work students.

\subsection{Limitations of the study}

It is important to note some limitations of the present study. First, the present study was crosssectional, thereby limiting the ability of the researcher to determine causality or temporality. Thus, it would be helpful for future studies to test the relationship between psychological capital and academic performance of social work students by using causal or prospective designs.

Secondly, the reliability of the scale used for the present study seems to be too low in relation to what is obtainable in some similar studies in developed countries. The relatively low reliability of the scale might indicate some measure of imperfection that could be attributed to the specificity of the students used for the pilot study. Thus, future studies should endeavour to use a more reliable scale or develop a culturally sensitive scale that would be peculiar to the Nigerian environment.

The third limitation of this study, concerns its sample, which consists of social work students from a Federal University in North-Central Nigeria. It is unknown to what extent the results would generalize to other groups such as graduate social work students or social work students in the State and private universities in other geo-political zones of Nigeria. A last limitation is that the GPA of the students was obtained through self-report, which potentially introduce social desirability bias. Nonetheless, the present study offers a germane evidence of the relationship between psychological capital and academic performance of social work students in Nigeria.

\section{Acknowledgments}

I would like to thank the many students who participated in the study. I am also grateful to the anonymous reviewers of the work for your insightful suggestions and corrections. 


\section{References}

Adegunju, K. A., Onivehu, A. O., Odetunde, O. A., \& Oyeniran, B. J. (2017). Cognitive and psychosocial predictors of Academic Achievement among pre-service teachers in University of Ilorin, Ilorin, Nigeria. Asia Pacific Journal of Multidisciplinary Research, 5(3), 84-92.

Adeyemo, D. A., \& Agokei, R. C. (2010). The moderating effects of mindfulness on the link between counseling self-efficacy and counseling effectiveness among pre-practical trainees in some Nigerian universities. Journal of Applied Psychology, 12(1), 1-18.

American Psychological Association. (2017). The road to resilience. Retrieved from http://www.apa.org/helpcenter/road-resilience.aspx

Badran, A. M., \& Youssef-Morgan, C. M. (2015). Psychological capital and job satisfaction in Egypt. Journal of Managerial Psychology, 30(3), 354-370.

Bamidele M., \& Bamidele, A. (2013). Influence of Cognitive performance on mathematics student's level of achievement. International Researcher, 2(1), 142-150

Bandura, A. (1997). Self-efficacy: The exercise of control. New York: W. H. Freeman.

Baumgardner, S. R., \& Crothers, M. K. (2010). Positive psychology. New Jersey: Pearson Education.

Carr, A. (2004). Positive psychology: The science of happiness and human strengths. New York: Routledge.

Feldman, D. B., \& Kubota, M. (2015). Hope, self-efficacy, optimism, and academic achievement: distinguishing constructs and levels of specificity in predicting college grade-point average. Learning and Individual Differences, 37, 210-216. https://doi.org/10.1016/j.lindif.2014.11.022

Froman, L. (2010). Positive psychology in the workplace. Journal of Adult Development, 17(2), 59-69.

Hayes, C. T., \& Weathington, B. L. (2007). Optimism, stress, life satisfaction and job burnout in restaurant managers. Journal of Psychology, 141(6), 565-79. https://doi.org/10.3200/JRLP.141.6.565-580

Kapikiran, N. A. (2012). Positive and negative affectivity as mediator and moderator of the relationship between optimism and life satisfaction in Turkish university students. Social Indicators Research, 106(2), 333-345.

Karmalkar, S. J., \& Vaidya, A. (2018). Resilience of rural-to-urban migrant adolescents: The role of gender and socio-economic status. Indian Journal of Health and Wellbeing, 9(1), 101-105.

Kleumper, D. K., Little, L. M., \& DeGroot, T. (2009). State or trait: effects of state optimism on jobrelated. Journal of Organizational Behavior, 30, 209-231. https://doi.org/10.1002/job.591

Kraimer, K., \& Altmeye, L. (2018). The relationship between social work and social pedagogy Similarities in theory and profession from a German perspective. Sociální pedagogika / Social Education, 4(1), 25-37. https://doi.org/10.7441/soced.2016.04.01.02

Kutanis, R. O., \& Oruc, E. (2014). A theoretical investigation on positive organizational behavior and positive psychological capital. The Journal of Happiness \& Well-Being, 2(2), 145-159.

Lunnbrg, F. (2010). Efficacy at work: Implications for motivation and performance. Journal of Auto Industry, 16(175), 32-35.

Luthans, B. C., Luthans, K. W., \& Jensen, S. M. (2012). The impact of business school students' psychological on academic performance. Journal of Education for Business, 87(5), 253-259.

Luthans, F. (2002). Positive organizational behavior: Developing and managing psychological strengths. The Academy of Management Executive, 16(1), 57-72. 
Onivehu / The relationship between psychological capital and academic performance...

Luthans, F., \& Youssef-Morgan, C. (2017). Psychological capital: an evidence-based positive approach. Annual Review of Organizational Psychology and Organizational Behavior, 4, 339-366. https://doi.org/10.1146/annurev-orgpsych-032516-113324

Luthans, F., Avey, J. B., \& Patera, J. L. (2008). Experimental analysis of a web-based training intervention to develop positive psychological capital. Academy of Management Learning \& Education, 7(2), 209-221.

Luthans, F., Avolio, B., Avey, J., \& Norman, S. (2007). Positive psychological capital: Measurement and relationship with performance and satisfaction. Personnel Psychology, 60(3), 541-572.

Luthans, F., Luthans, K. W., \& Luthans, B. C. (2004). Positive psychological capital: Beyond human and social capital. Business Horizons, 47(1), 45-50.

Luthans, F., Youssef, C. M., \& Avolio, B. J. (2007). Psychological capital. New York: Oxford University.

Luthar, S., Lyman, E. L., \& Crossman, E. J. (2014). Resilience and positive psychology. In M. Lewis \& K. D. Rudolph (Eds)., Handbook of Developmental Psychopathology: Third Edition (pp. 125-140). New York: Springer US. https://doi.org/10.1007/978-1-4614-9608-3_7

Martin, A. J., \& Marsh, H. W. (2009). Academic resilience and academic buoyancy: multidimensional and hierarchical conceptual framing of causes, correlates and cognate constructs. Oxford Review of Education, 35(3), 353-370.

McIntosh, B. J., Stern, M., \& Ferguson, K. S. (2004). Optimism, coping and psychological distress: Maternal reactions to NICU hospitalization. Children's Health Care, 33(1), 59-76.

Mwangi, C. N., Okatcha, F. M., Kinai, T. K., \& Ireri, A. M. (2015). Relationship between academic resilience and academic achievement among secondary school students in Kiamba County, Kenya. International Journal of School and Cognitive Psychology, 2(3), 1-5. https://doi.org/10.4172/2469-9837.S2-003

Ofole, N. M., \& Okopi, F. (2012). Therapeutic effect of rational emotive behaviour therapy in fostering self-efficacy amongst academically-at-risk-learners in National Open University of Nigeria. Global Advanced Research Journal of Educational Research and Reviews, 1(9), 211-218.

Ogunmakin, A. O., \& Akomolafe, M. J. (2013). Academic Self-efficacy, locus of control and academic performance of secondary school students in ondo state, Nigeria. Mediterranean Journal of Social Science, 4(11), 570-576.

Omilusi, M. (2016). The multi-dimensional impacts of insurgency and armed conflicts in Nigeria. Asian Journal of Social Sciences, Arts and Humanities, 4(2), 29-39.

Onivehu, A. O., \& Ohawuiro, O. E. (2018). Effect of powerpoint presentation on students' cognitive achievement in geography. Romanian Review of Geographical Education, 7(1), 46-60.

Onivehu, A. O., Adegunju, K. A., Ohawuiro, O. E., \& Oyeniran, K. A. (2018). The relationship among information communication technology utilization, self-regulated learning and academic performance of prospective teachers. Acta Didactica Napocensia, 10(4), 21-32.

Osemeke, M. (2011). Corruption and fraudulent practices by career civil servants and political appointees in Nigeria: The forms, causes and implications. Benin Journal of Social Sciences, 19(2), 180-189.

Ouweneel, E., Le Blanc, P. M., \& Schaufeli, W. (2012). Don't leave your heart at home: Gain cycles of positive emotions, resources, and engagement at work. CareerDevelopment International, 17(6), 537-556. 
Onivehu / The relationship between psychological capital and academic performance...

Peterson, S. J., Luthans, F., Avolio, B. J., Walumbwa, F. O., \& Zhang, Z. (2011). Psychological capital and employee performance: Latent growth modeling approach. Personnel Psychology, 64(1), 427450.

Rahat, E., \& Ihan, T. (2016). Coping styles, social support, relational self-construal, and resilience in predicting students' adjustment to university life. Educational Sciences: Theory and Practice, 16(1), 187-208. https://doi.org/10.12738/estp.2016.1.0058

Saeed, S., \& Murand, S. (2015). The relationship between psychological capital, educational selfregulatory and intelligence beliefs with students' academic performance in the University of Applied Sciences in Abdanan County. European Online Journal of Natural and Social Sciences, 4(1), 1705-1713.

Santilli, S., Nota, L., Ginevra, M. C., \& Soresi, S. (2014). Career adaptability, hope and life satisfaction in workers with intellectual disability. Journal of Vocational Behavior, 85(1), 67-74. https://doi.org/10.1016/j.jvb.2014.02.011

Seligman, M. (1991). Learned optimism. New York, NY: Pocket Books.

Sharabi, A., Sade, S., \& Margalit, M. (2016). Virtual connections, personal resources, loneliness, and academic self-efficacy among college students with and without LD. European Journal of Special Needs Education, 31(3), 376-390. https://doi.org/10.1080/08856257.2016.1141542

Shuaibu, S. S., Salleh, M. A., \& Shehu, A. Y. (2015). The impact of Boko Haram insurgency on Nigerian national security. International Journal of Academic Research in Business and Social Sciences, 5(6), 254-266.

Schunk, D. H., \& Zimmerman, B. J. (2008). Motivation and self-regulated learning: Theory, research and applications. New York: LEA.

Snyder, C. R., Harris, C., Anderson, J. R., Holleran, S. A., Irving, L. M., Sigmon, S. T., Yoshinobu, L. R., Gibb, J., Langelle, C., \& Harney, P. (1991). The will and ways: Development and validation of an individual-differences measure of hope. Journal of Personality and Social Psychology, 60(4), 570-585.

Snyder, C. R., Rand, K. L., \& Sigmon, D. R. (2002). Hope theory. In C. R. Snyder \& S. Lopez (Eds.), Handbook of positive psychology (257-276). Oxford, UK: Oxford University Press.

Stajkovic, A. D., \& Luthans, F. (1998). Self efficacy and work-related performance: A meta-analysis. Psychological Bulletin, 124, 240-261.

Thomson, K., Schonert-Reichl, K., \& Oberle, I. (2015). Optimism in early adolescence: Relations to individual characteristics and ecological assets in families, schools, and neighborhoods. Journal of Happiness Studies, 16(4), 889-913.

Uche, O. A., Uche, I. B., Eme, O. I., \& Ebue, M. O. (2014). Critical Appraisal of the relevance of field work practice in social work education in Nigeria. Mediterranean Journal of Social Sciences, 5(27), 1328-1334. https://doi.org/10.5901/mjss.2014.v5n27p1328

Uzorma, P. N., \& Nwanegbo-Ben, J. (2014). Challenges of hostage-taking and kidnapping in the Southeastern Nigeria. International Journal of Research in Humanities, Arts and Literature, 2(6), 131142.

Vanno, V., Kaemkate, W., \& Wongwanich, S. (2014). Relationships between academic performance, perceived group psychological capital and positive psychological capital of Thai undergraduate students. Procedia - Social and Behavioral Sciences, 116, 3226-3230. https://doi.org/10.1016/j.sbspro.2014.01.73 
Vitanya, V., Wanee, K., \& Suwimon, W. (2014). Relationships between academic performance, perceived group psychological capital, and positive psychological capital of Thai undergraduate students. Procedia - Social and Behavioural Sciences, 116, 3226-3230.

Youssef, C. M., \& Luthans, F. (2007). Positive organizational behavior in the workplace the impact of hope, optimism, and resilience. Journal of Management, 33(5), 774-800.

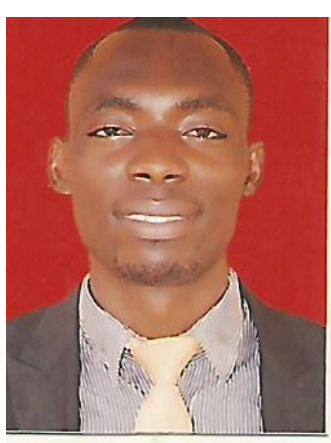

Adams Ogirima Onivehu is a postgraduate researcher in the Department of Social Sciences Education, University of Ilorin, Ilorin, Nigeria, where he specializes in the field of Educational Psychology. His diverse background and field experience in the fields of Educational Technology and Psychology, along with a gnawing curiosity, have resulted in a series of interdisciplinary research interests, which is reflected in several articles published by national and international outlets. He has attended many national and international conferences. 